\title{
PENGENDALIAN MANAJEMEN MODAL MANUSIA di PROGRAM STUDI: Sebuah Studi Fenomenologi
}

\author{
Wirawan ED Radianto ${ }^{1}$ dan Helena Sidharta \\ Universitas Ciputra \\ 1'wirawan@ciputra.ac.id
}

\begin{abstract}
The purpose of this research is investigating how Head of Department implement management control in their real context. This research use phenomenology and in-depth interview for collecting data.

This study found that Head of Department use many management control mechanism such as motivating, evaluation, giving opportunity, supporting, giving facilities, and role model. This research also found that department doesn't have specific mechanisms in order to implement management control.
\end{abstract}

Keywords: management control, phenomenology, head of department, motivation

\section{PENDAHULUAN}

Persaingan antar perguruan tinggi semakin meningkat di Indonesia. Dampak negatif dari persaingan tersebut sudah terlihat, sebagai contoh dengan ditutupnya sekitar 30 persen perguruan tinggi dari 300 perguruan tinggi di Sulawesi, Indonesia (Antara News, 2009). Ketua Asosiasi Perguruan Tinggi Swasta Indonesia (APTISI) menyatakan bahwa sekitar $40 \%$ dari sekitar 2.700 perguruan tinggi akan tutup jika mereka tidak memiliki keunggulan kompetitif (Elizabeth, 2008). Data lain menunjukkan bahwa sebanyak 5.000 program studi belum terakreditasi di Indonesia dan ada sekitar 6.000 program studi yang sampai 2010 belum diakreditasi dan yang sudah akreditasi tapi kadaluarsa (Harian Pelita, 2010; DemokratNews, 2010; Fitri, 2010). Hal tersebut tentu saja berdampak pada kualitas perguruan tinggi bersangkutan.

Menurut Ballow (2004) perguruan tinggi memiliki intellectual capital yang lebih besar dibandingkan dengan aset fisik dan termasuk dalam knowledge intensive firm (Ballow, 2004). Human Capital (HC) paling penting dibandingkan yang lainnya (Montazeri et al., 2013). Penelitian ini fokus pada program studi akuntansi karena karena standar lulusan program studi akuntansi harus mengikuti standar Internasional sesuai dengan International Federation of Accountant (IFAC). Lulusan akuntansi harus bisa bersaing dengan akuntan luar negeri, sehingga program studi harus benar-benar berkualitas. Sehingga pengendalian manajemen di program studi akuntansi menjadi isu yang penting dan menarik untuk diteliti. 
JURNAL

MANAJEMEN

INDONESIA

Vol. 15 - No.2

Agustus 2015
Penelitian ini dikembangkan dari penelitian Radianto (2011) yang telah melakukan penelitian sebelumnya. Penelitian tersebut menemukan bahwa kondisi dosen-dosen akuntansi di Indonesia dari segi kepangkatan akademik dan jenjang pendidikan masih belum baik. Masih banyak dosen yang belum memiliki kepangkatan akademik ( $41 \%$ dari total dosen akuntansi), berpendidikan S1 sebanyak $51 \%$ dari total dosen di Indonesia. Hal tersebut mengindikasikan pengendalian manajemen yang dilakukan belum optimal.

Tujuan penelitian ini untuk mengeksplorasi pengalaman KPS mengelola HC dalam konteks yang nyata. Sejauh yang penulis ketahui, penelitian yang menginvestigasi bagaimana KPS melakukan pengukuran kinerja dan pengembangan kompetensi dosen belum dilakukan. Kontribusi penelitian ini pada pengembangan ilmu pengendalian manajemen terutama di organisasi non profit serta menjadi model dasar pengendalian manajemen yang dapat dikembangkan.

\section{LANDASAN TEORI}

Mehta (2011) menyatakan bahwa HC dapat dikelola melalui career cycle yang mencakup planning, developing, retaining, dan acquiring. Pengelolaan kinerja $\mathrm{HC}$ yang dilakukan oleh organisasi harus sesuai dengan tujuan organisasi tersebut (Vandenabeele dan Hondeghem, 2008). Menurut mereka, pengelolaan HC termasuk bagaimana memotivasi karyawan sehingga mereka bekerja sesuai dengan tujuan organisasi. Pengelolaan HC melalui aktivitas pengukuran kinerjanya harus mampu meningkatkan nilai organisasi (Gotthard, 2007). Yeh dan Kung (2013) mengkaji pengukuran $\mathrm{HC}$ dengan value creation menemukan bahwa pengukuran kinerja $\mathrm{HC}$ selalu berhubungan dengan nilai perusahaan. Sedangkan Gates dan Langevin (2010) menyatakan bahwa pengukuran HC berdampak pada kinerja organisasi. Robinson (2009) menyatakan bahwa pengukuran HC berbeda antara satu organisasi dengan organisasi lainnya karena masing-masing organisasi memiliki kekhasan. Sienkiewicz (2014) menyatakan bahwa pengukuran HC harus disesuaikan dengan kondisi setiap organisasi, namun demikian pengukuran tersebut harus memiliki sistem yang terstruktur agar dapat efektif.

Menurut Anthony dan Govindarajan (2007) pengendalian manajemen adalah proses bagaimana manajer mempengaruhi para personel untuk memiliki perilaku sesuai harapan organisasi. Sedangkan Garrison dan Noreen (2000) menyatakan bahwa pengendalian manajemen sebagai sebuah proses yang memastikan bahwa pimpinan mengimplementasikan strategi serta memastikan semua sumberdaya organisasi berfungsi sesuai perencanaan. Sedangkan Herath (2007) menyatakan bahwa pengendalian manajemen merupakan prosedur yang diterapkan untuk mempengaruhi perilaku karyawan untuk mencapai visi dan misi organisasi. Demikian juga menurut Merchant dan Stede (2007) yang menyatakan bahwa pengendalian manajemen adalah alat yang ampuh untuk menangani perilaku individu. 
Paradigma penelitian ini adalah interpretif dimana penelitian ini memberikan pemahaman yang lebih mendalam mengenai mekanisme pengendalian manajemen dari sudut pandang informan dalam konteks sesungguhnya. Pendekatan Fenomenologi merupakan pendekatan filosofis untuk menyelidiki pengalaman manusia (Hajaroh, 2010). Pendapat tersebut menguatkan Husserl yang menyatakan bahwa ilmu pengetahuan selalu berpijak pada yang bersifat pengalaman (yang eksperiensial). Penelitian fenomenologi bertujuan untuk memahami dunia dari sudut pandang individu yang mengalami langsung fenomena tertentu serta makna yang ditempelkan padanya. Konsekuensinya metode fenomenologi tidak menggunakan hipotesis meskipun dapat menghasilkan hipotesis untuk diuji lebih lanjut. Fenomenologi tidak diawali dengan teori dan tidak menguji teori.

Dalam rangka menjawab pertanyaan bagaimana ("How") dan mengapa ("Why") maka peneliti menggunakan strategi studi kasus. Studi kasus dalam penelitian fenomenologi pernah dilakukan oleh Seaver (2010), Baah (2010), dan Solomon (2010). Pengambilan data dilakukan dengan teknik purposive sampling yaitu ketua program studi akuntansi di Kota Surabaya. Metode wawancara mendalam digunakan dalam penelitian ini untuk mengeksplorasi dengan mendalam karena metode wawancara mendalam merupakan salah satu metode utama dalam penelitain fenomenologi (Kuswarno, 2013).

\section{HASIL DAN PEMBAHASAN}

Informan yang dapat diwawancarai adalah 13 informan dari beberapa program studi di Akuntansi di Surabaya. Bagian ini menyajikan temuan di lapangan berkenaan dengan bagaimana implementasi pengendalian manajemen oleh para KPS.

\section{Motivasi untuk Meningkatkan Kinerja Dosen}

Penelitian ini mengeksplorasi bagaimana KPS memotivasi dosen dalam aktivitas Tri Dharma Perguruan Tinggi. Dari tiga aktivitas Tri Dharma perguruan tinggi, ternyata aspek pengajaran dianggap aspek yang utama, hal ini terlihat ketika mengungkapkan ketiga aspek tersebut maka aspek pengajaran merupakan aspek yang pertama kali disebutkan dengan jelas dan gamblang oleh KPS. Sspek pengajaran di beberapa kampus ternyata berbading lurus dengan pendapatan yang diperoleh oleh para dosen, sebagai contoh semakin dosen mengajar di banyak kelas maka akan semakin meningkat penghasilannya. Kebanyakan dosen juga mengajar di beberapa perguruan tinggi lainnya dan terdapat beberapa dosen yang memiliki bisnis sendiri.

Pada aspek pengajaran, cara pertama dosen adalah mengingatkan bahwa mengajar merupakan salah satu bentuk Tri Dharma Perguruan tinggi sehingga setiap dosen wajib untuk melakukannya. Beberapa informan selalu rajin untuk mengingatkan koleganya untuk tidak saja sibuk mengajar namun juga melakukan penelitian serta pengabdian masyarakat. KPS juga mengingatkan pentingnya melakukan penelitian dan pengabdian masyarakat disamping pengajaran yaitu adanya sertifikasi dosen (serdos). 
JURNAL

MANAJEMEN

INDONESIA

Vol. 15 - No.2

Agustus 2015
Cara kedua untuk proses evaluasi biasanya menggunakan kuesioner, sedangkan KPS melihat kinerja yang telah dilakukan oleh setiap dosen. Evaluasi memungkinkan maka mereka memberikan fakta mengenai bagaimana kinerja setiap dosen bersangkutan baik dalam melakukan aktivitas pengajaran. Disamping itu melalui evaluasi maka KPS dapat menangkap aspirasi mahasiswa mengenai dosen bersangkutan, bagaimana kinerjanya dilihat dari sudut pandang mahasiswa. KPS dapat melihat bagaimana tingkat kehadiran dosen, bagaimana cara menyampaikan materi perkuliahan, bagaimana cara dosen menilai tugas dan tes mahasiswa, dan yang tidak kalah pentingya adalah bagaimana perilaku dosen dalam kelas.

Evaluasi juga bertujuan untuk melihat bagaimana kemampuan dosen dalam mengajar apakah materi yang diberikan sesuai dengan yang sudah direncanakan. Hampir semua KPS berpendapat bahwa evaluasi merupakan cara yang sangat baik untuk memotivasi para dosen. Ketika dosen melihat bagaimana kinerja mereka yang dinilai oleh para mahasiswanya maka mereka akan memperbaiki kekurangan mereka dan akan meningkatkan dimana kekuatan mereka. Evaluasi juga merupakan proses awal bagi munculnya proses dialog antara KPS dan dosen bersangkutan. Proses dialog yang terjadi merupakan aspek penting dalam monitoring dosen karena proses tersebut dapat mengungkapkan banyak hal berkenaan dengan kinerja dosen. Melalui hasil evaluasi maka KPS dapat mengeksplorasi kekuatan dan kelemahan dosen dan bagaimana mengembangkan dosen bersangkutan.

Cara berikutnya untuk memotivasi dosen dalam aspek pengajaran yaitu memberikan kesempatan kepada para dosen untuk mengajar sesuai dengan kompetensinya. Hal ini sangat logis karena setiap dosen yang mengajar sesuai dengan kompetensinya akan menyampaikan materi dengan optimal. Dosen akan dapat memberikan contoh-contoh yang tepat dan mampu membuka wawasan mahasiswa dengan baik. Dosen pun akan mampu mengukur tingkat pemahaman mahasiswa melalui penugasan maupun ujian tengah dan akhir semester. Disamping itu melalui kompetensinya dosen akan merasa berkembang ilmunya terutama dosen yang akan mengambil studi lanjut (terutama S3) maupun dosen yang sudah menyelesaikan studi lanjutnya. Ketika ada dosen yang mengajar diluar kepakarannya/kompetensinya maka dosen tersebut akan kehilangan "ruh" mengajarnya, dosen tersebut tidak akan fokus mengajar sehingga berdampak pada pembelajaran yang dirasakan "hambar" oleh mahasiswa. Dampaknya mahasiswa tidak akan optimal menyerap apa yang disampaikan dosen, atau ilmu yang diberikan dosen akan sangat dangkal yang berdampak pada dangkalnya ilmu yang diserap oleh para mahasiswa. Usaha yang dilakukkan oleh KPS adalah membuat konsentrasi atau perumpunan untuk dosen-dosen. Seperti yang diungkapkan oleh salah satu KPS berikut ini: 
Dampak dari kebijakan tersebut adalah dosen akan lebih fokus dalam mencari materi, mengembangkan materi sampai dengan menyampaikan materi tersebut melalui berbagai cara karena dosen tersebut sudah sangat memahami materi yang disampaikannya mengingat materi tersebut merupakan kompetensinya. Salah satu aspek yang penting adalah ketika dosen mengajar sesuai dengan kompetensinya ternyata kompetensi tersebut adalah passion dosen bersangkutan. Sebagai contoh dosen yang sudah mengajar akuntansi manajemen maka yang bersangkutan pasti dengan baik dapat mengajar akuntansi biaya dan sistem pengendalian manajemen. Demikian juga dosen yang mengajar akuntansi keuangan maka akan dengan mudah mengajar akuntansi pengantar, akuntansi keuangan menengah, akuntansi keuangan lanjutan bahkan teori akuntansi. Oleh karena itu ketika dosen sudah terlalu lama mengajar akuntansi manajemen maka dosen tersebut akan merasa kesulitan ketika mengajarkan akuntansi keuangan. Hal tersebut ternyata dipengaruhi apakah dosen tersebut memiliki passion memperdalam ilmu akuntansi keuangan atau ilmu akuntansi manajemen, atau bahkan ilmu lainnya misalnya auditing dan perpajakan. Penelitian ini menunjukkan bahwa ternyata ketika KPS memberikan kesempatan kepada dosen untuk mengajar sesuai dengan kompetensinya atau passion maka akan mampu untuk memotivasi dosen dalam mengajar.

Ungkapan tersebut menyatakan bahwa para dosen memiliki keinginan untuk memperdalam kompetensi mereka dan hal tersebut sudah dipahami benar oleh para KPS. Menurut hampir seluruh KPS, mereka menyatakan bahwa dalam hal pengembangan ilmu mereka komitmen untuk meningkatkan kompetensi dosennya sesuai dengan kompetensinya. Para KPS telah mengirim para dosen untuk mengikuti seminar, call for papers, symposium, training dan aktivitas lainnya yang semuanya diarahkan untuk pengembangan kompetensi dosen. Namun demikian, nampaknya pengembangan kompetensi tersebut hanya untuk aspek pengajaran. Para dosen mengembangkan kompetensinya supaya dapat lebih meningkatkan kualitas pengajarannya. Penelitian dan pengabdian masyarakat masih dirasakan belum memiliki "tempat" bagi para dosen.

\section{Penelitian: Pergumulan yang Tidak Pernah Berhenti}

Penelitian oleh Radianto (2012) menunjukkan bahwa masih rendahnya penelitian yang dilakukan oleh dosen-dosen akuntansi seluruh Indonesia. Hal ini berdampak pada masih rendahnya jabatan fungsional yang dimiliki oleh dosendosen akuntansi di Indonesia. Dalam memotivasi agara para dosen mau melakukan penelitian maka berbagai cara harus ditempuh oleh KPS. Penelitian ini menunjukkan bahwa KPS melakukan cara-cara yang lebih banyak untuk memotivasi para dosen dibandingkan untuk memotivasi dosen mengajar.

Cara pertama dalam memotivasi dosen dalam melakukan penelitian adalah dengan cara memaksa dosen untuk melakukan penelitian. Dalam penelitian ini terungkap beberapa fakta mengapa dosen masih sulit untuk melakukan penelitian, adapun fakta-fakta tersebut adalah sebagai berikut.

Beberapa program studi ternyata memiliki jumlah dosen relatif masih sedikit. Kondisi ini ternyata menyebabkan dosen program studi akuntansi memiliki beberapa jabatan atau pekerjaan. Ada dosen yang merangkap sebagai pejabat struktural baik di lingkungan program studi, fakultas, maupun di luar fakultas.

Kondisi ini tentu saja mempersulit KPS untuk mendorong pada dosen melakukan penelitian. Kesulitan dalam membagi waku maupun prioritas merupakan masalah utama yang membuat para dosen sulit untuk melakukan penelitian. Dalam hal ini seringkali KPS "tidak memiliki kuasa" karena jabatan atau pekerjaan tersebut berasal dari pimpinan yang lebih tinggi. Demikian juga dengan dosen bersangkutan yang diberi tugas, mereka tidak dapat menolak penugasan tersebut.
131 
JURNAL

MANAJEMEN

INDONESIA

Vol. 15 - No.2

Agustus 2015
Kedua, banyak dosen akuntansi yang memiliki kesibukan di luar program studi. KPS mengungkapkan bahwa cukup banyak para dosen yang memiliki proyekproyek pribadi seperti menjadi konsultan atau memiliki usaha bisnis lainnya di luar program studi. Kondisi ini menyebabkan mereka akan "menomor duakan" penelitian karena secara finansial para dosen lebih diuntungkan mengerjakan proyek mereka dibandingkan dengan mengerjakan penelitian.

Berikutnya, para dosen masih relatif enggan melakukan penelitian karena mereka lebih fokus pada pengajaran dibandingkan penelitian, bahkan banyak dosen yang mengajar di universitas lain. Aspek yang menonjol ada beberapa dalam kasus ini adalah aspek finansial, aspek pertemanan dengan dosen dimana dia mengajar di universitas lain. Sebagai contoh ada dosen yang sewaktu mengikuti studi S2 atau S3 sekelas sehingga ketika lulus meminta bantuan temannya untuk mengajar di univesitasnya. Disamping aspek finansial, ternyata aspek aktualisasi diri juga memegang peranan yang penting bagi seorang dosen. Aspek aktualisasi diri ini dibagi dua yaitu dosen ingin dikenal oleh masyarakat luas atau masyarakat akademisi dan dosen ingin memberikan pengetahuannya kepada masyarakat. Sebagai contoh ada dosen yang menulis buku dan dosen tersebut ingin mensosialisasikan buku tersebut. Salah satu caranya adalah dengan mengajar di tempat lain untuk "menyebarkan" hasil karya ilmiahnya.

Penyebab lainnya bagaimana dosen lebih condong untuk tidak mengerjakan penelitian yaitu adanya reward. Ada program studi yang memberikan reward kepada dosen yang berprestasi dengan cara menambah jumlah kelas kepada dosen tersebut. Hal ini tentu saja berdampak pada tingginya aktivitas mengajar dosen bersangkutan sehingga mengurangi waktu dalam melakukan penelitian dan pengabdian masyarakat. Faktor lainnya adalah ternyata banyak dosen terutama dosen muda yang merasa tidak mampu melakukan penelitian. Beberapa kesulitan pada saat ketika harus mencari ide penelitian, menggunakan metode penelitian, menggunakan alat analisis statistika, serta sulit untuk "menulis". Ada dosen muda yang harus "dibimbing khusus" oleh KPS mulai dari mencari ide sampai dengan bagaimana menulis yang baik dan benar. Namun akhirnya dengan ketekunan yang luar biasa dosen tersebut berhasil mempresentasikan penelitiannya di seminar internasional, bahkan setelah itu dosen bersangkutan mulai rajin untuk mengikuti seminar-seminar untuk mempresentasikan penelitiannya.

Faktor selanjutnya adalah dosen merasa lebih baik menggunakan waktunya untuk mengerjakan aktivitas lain dibandingkan melakukan penelitian yang dianggap masih sulit. Aktivitas lain yang dimaksud disini adalah hobi dari dosen-dosen tersebut. Namun setelah diinvestigasi lebih lanjut ternyata faktor yang menyebabkan mengapa para dosen lebih enggan melakukan penelitian ternyata passion merupakan aspek yang sangat penting. Peneliti menemukan bahwa passion untuk meneliti masih rendah dibandingkan dengan mengajar.

Melihat hal tersebut ternyata para KPS tidak tinggal diam, mereka telah melakukan beberapa cara untuk membuat para dosen melakukan penelitian. Beberapa cara berikut ini digunakan oleh KPS agar para dosen mulai menyadari pentingnya penelitian dan lebih dari itu merekapun berusaha untuk menciptakan budaya meneliti di kalangan para dosen. KPS memaksa para dosen untuk melakukan penelitian karena penelitian merupakan salah satu aspek yang paling penting dalam Tri Dharma Perguruan Tinggi. 
Beberapa contoh ungkapan tersebut memperlihatkan bagaimana KPS memotivasi dosen melalui aturan yaitu KPS ingin menyadarkan tanggung jawab seorang dosen adalah melakukan kegiatan penelitian. KPS menyatakan bahwa ketika seseorang secara sadar berkarir sebagai dosen maka dia harus memenuhi Tri Dharma perguruan tinggi yaitu pengajaran, penelitian, dan pengabdian masyarakat. Melalui penelitian maka akan berdampak pada meningkatya kinerja program studi. Sehingga KPS tidak bosan-bosannya selalu mengingatkan bahwa penelitian merupakan aspek yang harus dilakukan oleh para dosen tanpa terkecuali. Dalam rangka mendorong para dosen hampir semua KPS memberikan kesempatan para dosen untuk mengikuti pelatihan metode penelitian.

Selanjutnya KPS juga mendorong dosen untuk meneliti karena berhubungan dengan sertifikasi dosen. Dalam hal ini peneliti menemukan bahwa melalui sertifikasi dosen ini KPS lebih mudah untuk mewajibkan dosen dalam meneliti. Hal ini karena didorong oleh faktor "reward" yang diberikan oleh negara untuk dosen yang melakukan Tri Dharma perguruan tinggi dan bagi dosen yang sudah tersertifikasi. Dalam hal ini aspek finansial ternyata dapat menentukan prioritas bagi dosen. Tentu saja setiap dosen yang sudah tersertifikasi tidak akan menyianyiakan kesempatan ini. Disamping itu program studi juga harus terus mengelola para dosen untuk tetap bersertifikasi dalam rangka meningkatkan kualitas dan citra program studi. Sebagai contoh saat ini sertifikasi sudah masuk ke dalam salah satu aspek penilaian akreditasi program studi.

Beberapa KPS berupaya untuk meningkatkan jumlah penelitian dengan mendorong dosen untuk melakukan penelitian yang tidak harus dilakukan secara individu tetapi juga berkelompok. Latar belakang mengapa KPS mendorong dosen untuk melakukan penelitian berkelompok adalah agar luaran penelitian di program studi meningkat. Disamping itu agar dosen yang menjabat sebagai tenaga struktural juga memiliki kesempatan untuk melakukan penelitian. Demikian juga dengan dosen yang masih yunior dalam penelitian dapat meningkatkan kompetensinya melalui bimbingan dosen yang lebih senior.

Sampai saat ini KPS tidak pernah menyatakan tingkat atau standar kualitas penelitian yang terbaik. Sehingga penulis berpendapat untuk tahap ini KPS baru pada tahap bagaimana mengembangkan budaya meneliti bagi para dosennya. Tujuannya saat ini bukan pada kualitas penelitian namun baru sampai pada kuantitas penelitian.

Untuk meningkatkan kuantitas penelitian KPS memotivasi dosen dengan cara mengajak dosen-dosen untuk meneliti. Latar belakang mengapa KPS mengajak dosen untuk meneliti karena ada beberapa dosen yang tidak mampu secara optimal waktunya dalam meneliti, kasus ini terjadi pada dosen-dosen yang memiliki jabatan struktural. Mereka tidak mungkin melakukan penelitian sehingga mereka akan didorong untuk mengikuti penelitian dosen lainnya, hal ini berdampak positif yaitu dosen yang memiliki jabatan struktural mau untuk bergabung dalam tim peneliti.

Demikian juga beberapa KPS memprakarsai untuk mengajak para dosen melakukan penelitian. Cara yang dipakai oleh KPS ini sangat menarik karena yang bersangkutan langsung memberikan contoh dan teladan kepada para dosen dalam melakukan penelitian. Hal ini timbul dari semangat kepemimpinannya untuk mengembangkan para dosen di program studi melalui caranya yaitu menginspirasi para dosen dalam melakukan penelitian.

Cara lainnya adalah dengan memberikan fasilitas kepada para dosen dalam meneliti. Kegiatan ini bekerja sama dengan lembaga lainnya misalnya lembaga penelitian universitas sebagai lembaga untuk mendukung proses penelitian maupun lembaga internal lainnya untuk memfasilitasi dalam hal keuangan dan hal lainnya sehingga para dosen dapat mempresentasikan hasil penelitiannya pada kegiatan ilmiah. 
JURNAL

MANAJEMEN

INDONESIA

Vol. 15 - No.2

Agustus 2015
KPS memberikan fasilitas dalam rangka mendorong dosen untuk lebih mudah melakukan penelitian, sehingga dengan bantuan lembaga penelitian maka para dosen akan diberikan bekal dalam metode, alat, bahkan bagaimana cara penulisan penelitian. Demikian juga dengan penyediaan jurnal, maka para dosen tidak akan kesulitan untuk memperoleh dokumentasi maupun data penelitian. Hal berikutnya yang tidak kalah pentingnya adalah memberikan fasilitas kepada dosen untuk mempresentasikan penelitiannya pada kegiatan seminar-seminar. Hal ini tentu saja memberikan dampak positif, yaitu meningkatkan percaya diri dosen dan kebanggaan dosen tersebut serta meningkatkan citra program studi di tingkat nasional. Hal ini nampak dari salah satu informan yang sangat bangga ketika salah seorang dosennya menjadi pemakalah terbaik tingkat nasional. Dampak dari kegiatan ini sangat positif, yaitu akan mendorong dosen-dosen lain untuk berpartisipasi dalam penelitian.

\section{Pengabdian Masyarakat: Dharma yang tersulit?}

Pengabdian masyarakat merupakan aspek penting dalam Tri Dharma Perguruan Tinggi yang menunjukkan bagaimana peran perguruan tinggi di tengahtengah masyarakat. Pengabdian merupakah salah satu aspek penting sebagai "ladang sesungguhnya" untuk para dosen menerapkan apa yang pernah diteliti sebelumnya. Sudah seharusnya setiap dosen memiliki semangat untuk pengabdian masyarakat.

Namun hal ini bertolak belakang dengan kondisi yang ada di lapangan. Penelitian ini menunjukkan bahwa pengabdian masyarakat bukan merupakan hal yang lebih penting dibandingkan dengan pengajaran dan penelitian. Hal ini dapat dipahami karena pengabdian masyarakat di proses jabatan fungsional dan akreditasi program studi memiliki nilai yang lebih rendah dibandingkan dengan pengajaran dan penelitian. Namun demikian pengabdian masyarakat harus tetap dilakukan karena merupakan bagian dari Tri Dharma perguruan tinggi. Penelitian ini menemukan bahwa aspek pengabdian masyarakat merupakan aspek yang lebih sulit dibandingkan dengan pengajaran dan penelitian, terutama dalam "menemukan" dan "mengembangkan" kegiatan pengabdian masyarakat. Beberapa usaha KPS dalam meningkatkan motivasi para dosen melakukan pengabdian masyarakat yaitu mengikutsertakan para dosen dalam kegiatan pengabdian masyarakat pada tingkat fakultas atau universitas.

Penelitian ini menemukan bahwa pengabdian masyarakat terkesan bukan sesuatu yang sangat penting. Untuk menanggulangi kesulitan pengabdian masyarakat maka KPS mengikutsertakan dosen pada kegiatan lembaga lain. Aktivias ini menunjukkan bahwa karena sulitnya program studi mengadakan pengabdian masyarakat maka program studi memerlukan dukungan dari pihak lain atau aktivitas lain, walaupun ada satu KPS yang sudah memiliki program tersebut namun program tersebut belum terealisasi sampai saat penelitian ini berlangsung. Kondisi ini menunjukkan bahwa pengabdian masyarakat bukan sesuatu yang sangat penting bagi program studi, yang penting ada dan itu sudah cukup. Beberapa KPS masih memiliki idealis yang tinggi yaitu ketika memaksa setiap dosen melakukan pengabdian masyarakat karena merupakan bagian penting dari Tri Dharma perguruan tinggi. 
Dengan tujuan supaya para dosen memiliki Tri Dharma Perguruan Tinggi maka KPS memaksa para dosen untuk melakukan pengabdian masyarakat. Hal ini dapat dilihat dari beberapa KPS yang memberikan target keluaran untuk setiap periode bagi setiap dosen terutama yang memiliki sertifikasi dosen. Latar belakang dari mengapa KPS memotivasi dengan cara ini adalah kembali mengingatkan peran dosen ada tiga yaitu Tri Dharma Perguruan Tinggi. Seseorang ketika dengan sadar memilih profesi sebagai dosen berarti harus siap untuk melakukan pengabdian masyarakat, demikian juga setiap dosen yang sudah tersertifikasi sebagai tenaga pendidik harus memiliki minimal satu pengabdian masyarakat. Proses ini pada akhirnya berdampak pada kinerja program studi yang dikelola oleh KPS. KPS harus bisa meningkatkan kinerja program studi, dalam hal ini kinerja program studi adalah kinerja para dosennya, sehingga KPS harus memotivasi kinerja para dosen supaya memiliki kinerja yang optimal. Proses ini juga sebenarnya menguntungkan bagi karir individu dosen. Semakin dosen tersebut mampu untuk melakukan pengajaran dengan baik, penelitian yang berkualitas, serta pengabdian masyarakat yang tepat maka karir jabatan fungsionalnya juga akan meningkat.

\section{Mengukur Kinerja Dosen}

Bagian ini menyajikan bagaimana KPS mengukur kinerja dosen dalam melakukan Tri Dharma Perguruan Tinggi. Ketika KPS mampu untuk memotivasi para dosen maka ketika dosen tersebut sudah melakukan kegiatan Tri Dharma Perguruan Tinggi maka KPS harus bisa mengukur sampai sejauh mana pencapaian para dosen. Proses pengukuran tersebut menggunakan sistem pengukuran yang diterapkan di tingkat program studi, baik yang dibuat oleh program studi maupun fakultas bahkan universitas. Namun demikian penelitian ini menemukan ada beberapa program studi yang merasa tidak memiliki sistem pengukuran kinerja khusus. Beberapa program studi memiliki sistem punishment bagi dosen yang melanggar tetapi tidak memiliki sistem "reward khusus" bagi dosen yang berprestasi. Hal ini tentu saja dapat menjadi penyebab mengapa para dosen tidak melakukan kegiatan Tri Dharma Perguruan Tinggi atau jikapun melakukan tidak melakukan dengan optimal. Hampir semua program studi menyatakan bahwa sistem pengukuran kinerja yang mereka miliki merupakan sistem sentralisasi, yaitu dikelola oleh universitas dan sistem yang diterapkan dari pemerintah yaitu Beban Kerja Dosen yang setiap regular digunakan sebagai bagian dari persyaratan pengajuan untuk sertifikasi dosen.

Beberapa informan menyatakan bahwa pengukuran dilakukan melalui lembaga penjaminan mutu (atau bisa dengan nama lain misalnya Gugus Kendali Mutu) atau lembaga lainnya, misalnya departemen Sumber Daya Manusia (SDM). Beberapa KPS menyatakan bahwa sistem pengukuran kinerja belum terlalu berjalan dan sama dengan beberapa program studi lainnya pengukuran kinerja masih dilakukan secara terpusat kepada universitas.

Penelitian ini menemukan bahwa proses pengukuran kinerja untuk Tri Dharma Perguruan Tinggi dilakukan dalam tingkat universitas. Peneliti berpendapat bahwa proses ini sulit untuk mengukur kinerja program studi secara tepat, karena setiap program studi memiliki kekhasannya sendiri. Sebagai contoh program studi yang masuk dalam rumpun eksakta akan berbeda dengan program studi yang masuk dalam rumpun sosial. Demikian juga dengan program studi yang sama-sama sosial memiliki kekhasan yang berbeda misalnya program studi ilmu komunikasi dengan program studi Akuntansi, bahkan program studi akuntansi dapat memiliki kinerja yang berbeda dengan program studi manajemen walaupun keduanya masih dalam rumpun yang sama yaitu ekonomi. Kondisi ini menyulitkan program studi untuk dapat "memotret" kinerjanya. 
JURNAL

MANAJEMEN

INDONESIA

Vol. 15 - No.2

Agustus 2015
Dalam proses pengukuran kinerja, para dosen yang memiliki prestasi ternyata tidak diberikan penghargaan/rewards khusus. Semua program studi menyatakan tidak menyediakan penghargaan bagi dosen yang berprestasi. Namun demikian terdapat satu program studi yang memberikan penghargaan untuk dosen yang beprestasi yaitu KPS memberikan tambahan kelas bagi dosen yang berprestasi. Menurut peneliti hal ini dinilai kurang tepat karena dengan menambah kelas maka beban dosen bersangkutan akan semakin besar yang berdampak pada pengurangan kegiatan Tri Dharma lainnya yaitu penelitian dan pengabdian masyarakat.

Peneliti melihat bahwa para informan cukup kesulitan menjelaskan mengenai sistem pengukuran kinerja. Hal ini dapat dimaklumi karena sistem tersebut tidak didesain oleh program studi, bahkan dalam pembuatan sistem tersebut nampaknya tidak melibatkan program studi. Demikian juga ketika menjelaskan mengenai reward dan punishment, para informan terkesan sulit untuk menjawab. Hal ini memberi kesan bahwa sistem pengukuran kinerja termasuk reward dan punishment bukan merupakan faktor penting dalam operasional program studi. Kemudian sampai saat ini belum ada kesan adanya permasalahan mengenai dosen yang bermasalah. Malahan ada kesan bahwa program studi "membebaskan" para dosen untuk melakukan banyak hal sepanjang tidak mengganggu proses mengajar. Dalam hal reward dan punishment, nampak ketidak adilan yaitu ketika dosen melakukan kesalahan maka diberikan punishment tetapi ketika dosen berprestasi tidak diberikan penghargaan khusus. Kondisi ini tentunya berdampak besar pada motivasi dosen yang pada akhirnya pada kinerja dosen. Dosen akan cenderung untuk melakukan aktivitasnya hanya untuk mencukupi angka kredit saja bukan memberikan yang terbaik. Sehingga dosen akan "mencari" aktivitas lain di luar program studi yang menurutnya lebih menguntungkan. Bila hal ini terjadi maka mahasiswa yang pada akhirnya akan dirugikan dan tentu saja berdampak buruk pada citra program studi.

\section{Mengembangkan Kompetensi Dosen}

Proses pengukuran kinerja pada akhirnya akan berdampak pada identifikasi kelemahan dan kekuatan dosen. Ketika hasil kinerja dosen sudah diketahui maka pimpinan akan melihat kompetensi apa yang harus diberikan oleh dosen jika dosen tersebut memiliki kekurangan, selanjutnya kompetensi apa yang harus ditingkatkan ketika dosen sudah memiliki kompetensi tersebut. Bagian ini menjelaskan bagaiana KPS mengembangkan kompetensi para dosennya.

KPS memberikan informasi mengenai kesempatan mengikuti seminar dan kegiatan lainnya kepada para dosen. Tujuannya adalah agar dosen tertarik untuk mengikuti kegiatan tersebut dan meningkatkan kompetensinya. KPS tidak mendorong agar mengikuti kegiatan tersebut. KPS lebih mengambil sikap pasif yaitu hanya memberikan informasi, selanjutnya terserah kepada para dosen. Dalam hal ini terlihat KPS tidak menginspirasi para dosen tetapi lebih fungsinya pada "Radio" yaitu memberikan informasi. Kondisi ini baik dilakukan jika para dosen sudah memiliki kesadaran tinggi untuk melakukan Tri Dharma Perguruan Tinggi. Namun pada kenyataannya passion ini belum ada. Oleh karena itu penulis menilai bahwa cara seperti ini tidak efektif untuk dilakukan.

Namun demikian ada beberapa KPS yang mau untuk mendorong para dosen untuk mengikuti berbagai kegiatan Tri Dharma Perguruan Tinggi. Beberapa KPS dengan sengaja merencanakan pengembangan para dosennya. Beberapa KPS menyatakan bahwa mereka membuat rencana kerja untuk pengembangan para dosen. 
Perencanaan yang dibuat oleh beberapa KPS menunjukkan bahwa mereka sangat perhatian pada pengembagan sumberdaya manusianya. Mereka melihat bahwa dosen adalah HC yang harus diprioritaskan dan dikembangkan. Sedangkan KPS yang lain mendorong untuk mengirimkan para dosen ketika ada kesempatan yang dapat meningkatkan kompetensi dosen. Hampir semua KPS mengirimkan para dosen sesuai dengan bidangnya agar mereka dapat meningkatkan kompetensinya. Ada KPS tidak hanya mendorong para dosen untuk mengikuti kegiatan pelatihan dan seminar-seminar, namun bahkan mewajibkan para dosen untuk mengembangkan dirinya.

Uraian pada bagian ini menjelaskan bahwa dosen merupakan aset yang sangat penting bagi program studi. Hal ini dapat dilihat dari beberapa KPS yang mendorong para dosen untuk mengembangkan dirinya, bahkan beberapa KPS dengan sengaja merencanakan pengembangan para dosen. Ada juga yang menyelenggarakan program internal untuk pengembangan dosennya. Walaupun demikian ada beberapa KPS yang nampaknya tidak terlalu fokus ke pengembangan dosen. Konsep pengembangan dosen nampaknya hampir sama untuk setiap program studi, yaitu setiap dosen dikembangkan sesuai dengan minat dan kompetensinya.

Dengan mengembangkan pendekatan secara personal maka KPS tidak dalam posisi sebagai atasan dan bawahan, namun sebagai partner. Dalam posisi sebagai partner maka para dosen akan lebih bebas mengungkapkan gagasannya maupun hal-hal lain berkenaan dengan program studi, pengajaran, penelitian, maupun pengabdian masyarakat. Para dosen dapat memberikan kritik dan saran yang konstruktif karena merasa dihargai sebagai partner. Ide-ide kreatif dapat muncul karena kurangnya "tekanan" sehingga dapat meningkatkan inovasi yang ada di program studi. Program-program yang dihasilkan dari pertemuan rutin atau wajib tidak akan dapat dilaksanakan tanpa koordinasi informal. Melalui koordinasi informal biasanya masalah teknis dapat diselesaikan dan para dosen dapat meningkat motivasinya karena merasa dihargai.

Peneliti mengeksplorasi hal-hal apa saja yang seringkali didiskusikan oleh KPS dan staf dosen. Dua topik yang seringkali menjadi perbincangan adalah masalah akademik dan mahasiswa. Berikut ini adalah beberapa topik yang seringkali dibicarakan berkenaan dengan masalah akademik. KPS seringkali mendiskusikan bagaimana proses perkuliahan. Dimulai dari bagaimana proses perkuliahan awal semester, bagaimana membagi matakuliah, apa yang menjadi materi pengajaran serta literatur apa yang akan digunakan. Bagi salah seorang informan hal tersebut termasuk di dalamnya bagaimana perancangan KKN dan buku pedoman untuk para mahasiswa. 


\section{KESIMPULAN}

JURNAL

MANAJEMEN INDONESIA

Vol. 15 - No.2

Agustus 2015
Penelitian ini mengeksplorasi bagaimana KPS mengelola HC yang ada di program studi. KPS memotivasi staf dosen untuk melakukan pengajaran, penelitian, dan pengabdian masyarakat melalui beberapa cara yaitu sebagai berikut:

Dalam aspek pengajaran maka KPS memotivasi dengan cara mengingatkan peran dosen dalam Tri Dharma Perguruan Tinggi, melakukan evaluasi secara berkala, dan memberikan kesempatan pada dosen untuk mengajar sesuai kompetensinya. Dalam aspek penelitian maka KPS melakukan beberapa hal, yaitu memaksa dosen melakukan penelitian, mendorong dosen melakukan penelitian, mengajak dosen yang tidak meneliti untuk meneliti bersama-sama, memberikan contoh kepada staf dosen, memfasilitasi dosen dalam melakukan penelitian.

KPS mengukur kinerja dosen berdasarkan peraturan dan standar yang ada di universitas. Sistem rewards dan punishment tidak berjalan dengan baik karena tidak adanya keseimbangan antara punishment yang diterapkan dengan rewards yang tidak pernah diterapkan. Kondisi ini nampaknya memang sudah menjadi hal yang wajar karena aspek rewards dan punishment biasanya diterapkan di organisasi bisnis dengan konsep manajerial, sedangkan perguruan tinggi adalah organisasi tidak bermotif laba dan masih menganut konsep kolegialisme. KPS mengembangkan kompetensi dosen dengan beberapa cara yaitu memberikan informasi dosen untuk mengembangkan diri, membuat rencana kerja untuk mengembangkan para dosen, mendorong dosen untuk mengikuti kegiatan dalam rangka pengembangan diri, menyelenggarakan program internal untuk pengembangan dosen, dan mewajibkan dosen untuk mengembangkan dirinya.

Hambatan KPS dalam memotivasi para dosen untuk melakukan Tri Dharma Perguruan tinggi adalah adanya aspek kolegialisme dalam perguruan tinggi yang sudah menjadi ciri khas pengelolaan perguruan tinggi. Sehingga para KPS tidak bisa memaksa dengan mengedepankan reward and punishment. Hambatan lainnya yaitu aktualisasi para dosen di luar perguruan tingginya yaitu ketika mereka memiliki proyek-proyek dan mengajar di perguruan tinggi lainnya berdampak pada belum termotivasinya para dosen untuk meneliti dan melakukan pengabdian masyarakat.

Penelitian ini dapat dikembangkan dengan memperluas salah satu aspek penting yaitu kepemimpinan dari KPS. Pendekatan penelitian juga dapat dikembangkan yaitu menggunakan pendekatan kuantitatif untuk mengkonfirmasi hasil penelitian ini. Ruang lingkup penelitian ini dapat dikembangkan lebih luas secara geografis atau memperluas obyek penelitian yaitu tidak hanya bidang akuntansi tetapi juga manajemen dan studi pembangunan yang memiliki rumpun sama. Penelitian selanjutnya penting dilakukan karena akan mampu menggali faktor apa saja yang mempengaruhi dosen dalam melakukan Tri Dharma Perguruan Tinggi. 
(2010) 35\% program studi PTS di Jawa Barat Banten Belum Diakreditasi. Demokrat News. 27 April. (2010) Sebanyak Lima ribu prodi belum terakreditasi. Harian Pelita. 26 Oktober

Antara (2009) Kopertis tutup 30 persen prodi PTS Se-Sulawesi, 19 Oktober

Anthony, R.N. and Govindarajan, V. 2007. Management Control System $12^{\text {th }}$, New York: McGraw-Hill

Baah, A. (2010). Resource Communication Technology and Marketing of Textile Products: A U.S. Textile Industry Case Study. Dissertation. College of Graduate Studies. University of Phoenix

Ballow, J., Burgman, R., Roos, G., and Molnar. M., (2004), A New Paradigm for Managing Shareholder Value, Accenture Institute for High Performance Business

Bungin, B. (2007). Penelitian Kualitatif: Komunikasi, Ekonomi, Kebijakan Publik, dan IImu sosial lainnya edisi 2, Penerbit Kencana Prenada media Group

Elizabeth, Stevani (2008) Ribuan Perguruan Tinggi Swasta Terancam Tutup. Sinar Harapan, 4 April hal.8

Fisher, J.E., (1998). Contingency Theory, Management Control Systems and Firm Outcomes : Past Result And Future Directions. Behavioral Research in Accounting. 10. 48-63.

Fitri (2010) Ada 6000 program studi antre akreditasi. 20 Desember. Diakses dari www.kopertis.go.id tanggal 3 Maret 2011.

Garrison, R.H. \& Noreen, E.W. (2000). Managerial Accounting, 9th edition. Irwin McGraw Hill dalam Zheng, T. 2012. Balancing The Tensions Between The Control And Innovative Roles of Management Control Systems: A Case Study of Chinese Organization. Doctor of Business Administration Thesis. University of Northumbria at Newcastle, UK

Gates, S., Langevin, P (2010) Human capital measures, Strategy, and Perfomance: HR Managers' perceptions. Accounting, Auditing \& Accountability Journal. 23 (1).111-132

Gotthard, P (2007) Human capital measurement, ambiguity, and opportunism: actors between menace and opportunity. Zeitchrift fur Personalforschung. 21 (3). 252-273

Hajaroh, M. (2010). Paradigma, Pendekatan, dan Metode Penelitian Fenomenologi, Penelitian, Universitas Negeri Yogyakarta: Yogyakarta.

Herath, S.K. (2007). A Framework for Management Control Research. Journal of Management Development. 26 (9). 895-915

Kaplan, R \& Norton, D.P. (2004) Strategy Maps: converting Intangble Assets Into Tangible Outcomes. Boston, Massachusetts: Harvard Business School Press

Mehta, A. (2011) Human capital management: A Comprehensive approach to augment organizational performance. Review of Management. 1(2). 44-58

Merchant, Stede. (2007). Management Control Systems: Performance Measurement, Evaluation, and Incentives. $2^{\text {nd }}$ edition. Prentice Hall.

Montazeri, M., Hosseini, A.M., Forghani, M.A. (2013). Evaluation of Relationship between Intellectual Capital and Structure of Organizational Corporate Entrepreneurship (CE) (Case Study: Staff of Maskan Bank, Kerman Province). International Research Journal of Applied and Basic Sciences, 6 (1). 29-35

Radianto, W. (2012) Do we ready to face globalization of Accounting? Exploratory Study of Accounting faculties in Indonesia. Proceeding ISIEM: "'Innovation in technology, information, and management concerning worldwide economic challenge". International seminar, ISSN: $1978-774 x$

Radianto, W. (2012).

Robinson, D (2009) Human capital measurement: an approach that works. Strategic Review. $8(6) .5-11$

Seaver, D. (2010). Effect of Transformational Leadership in A Cross-Cultural Organization: A Case Study. Dissertation. Cappela University 
Sienkiewicz, L (2014) Human capital measurement practices in Polish companies empirical evidence. European Conference on Intellectual Capital, pp. 217-225

MANAJEMEN INDONESIA

Vol. 15 - No.2

Agustus 2015
Solomon, Y. (2010). From Startup to Maturity: A Case Study of Employee Creativity Antecedents in High Tech Companies. Dissertations. Capella University

Vandenabeele, W., Hondeghem, A. (2008) No Easy path to HRM performance measurement systems: Exploring the introduction of the US human capital assessment and accountability framework and the flemish management code. Public Personnel Management. 37(2). 243-260

Yeh, C., Kung, F. (2013) Aligning human capital measurement with corporate value creation: evidence from the taiwan electronics industry. The International Journal of Business and Finance Research. 7 (5). 35-47 